PN Ir38

\title{
Isolation and characterization of some Bence-Jones proteins
}

For several years we have been investigating the proteins in the urine of patients suffering from myelomatosis ${ }^{1-3}$. This note concerns our patients Nos. IOI, Iog, IIo and III. Tested by the method of PUTNAM ${ }^{4}$ the urine of each patient contained proteins, coagulating at $56^{\circ}$ and redissolving at $100^{\circ}$.

The results of free-boundary electrophoresis and starch-gel electrophoresis ${ }^{5}$ of the crude protein mixtures showed that the samples were far from homogeneous. Several of the fractions discernible in the latter method appeared to be normal serum proteins (see ref. 3 ).

The major Bence-Jones fractions were isolated from the crude mixtures by means of ion-exchange chromatography on DEAE-Sephadex A-5o or CM-Sephadex C-5o and finally by gel filtration on Sephadex G-Ioo and on Sephadex G-200. The buffer systems used in ion-exchange chromatography were phosphate solutions of increasing molarity (0.005-O.I $M$ ) and decreasing $\mathrm{pH}$ for DEAE-Sephadex and acetate solutions of increasing molarity $(\mathrm{O} . \mathrm{OI}-\mathrm{O} . \mathrm{I} M)$ and $\mathrm{pH}$ for CM-Sephadex. The results obtained with these ion exchangers are assembled in Fig. $I^{\star}$. The shadowed major fractions were submitted to gel filtration on Sephadex G-IOo (Lot To 33, I40-400 mesh) and on Sephadex G-200 (Lot I20, I40-400 mesh) in o.or $M$ Tris-HCl buffer ( $\mathrm{pH} 7.6$ ). The results are shown in Fig. $2^{\star}$. The fractions shadowed are, according to their starchgel electrophoresis diagrams, sufficiently purified for a chemical analysis. The analytical results are assembled in Table $I^{*}$. They show that proteins Nos. IOI, IOg and II have the same $\alpha$-amino terminal amino acid (aspartic acid) and the same carboxyl terminal amino acid (leucine), while these amino acids are tyrosine and alanine, respectively, in protein No. III. The 4 amino acids preceding the carboxyl terminal amino acid differ from protein to protein. We also determined the percentages by weight of some amino acids in the proteins, by specific methods, as well as their content of glucidic components and their sedimentation constants. As Table I shows, these quantities were also different.

A full account of this work will be published.

\section{Laboratory for Physiological Chemistry and Department of Internal Medicine, The University, Utrecht (The Netherlands)}

H. G. VAN EIJK

C. H. Monfoort

J. J. WiTTE

H. G. K. WESTENBRINK

1 O. J. Ten Thije, Acta Med. Scand., I53 (1956) 253.

2 J. J. Witte, D. Pragay and H. G. K. Westenbrink, Proc. Kon. Nederl. Alad. Wetensch., Series C, 63 (1960) 646.

3 G. Hennemann, H. G. Van Eijk, J. J. Witte and H. G. K. Westendrink, Proc. Kon. Nederl.

Akad. Wetensch., Series C, (to be communicated on October 27 th, 1962).

${ }^{4}$ F. W. Putnam, Arch. Biochem. Biophys., 83 (I959) I 5.

${ }^{5}$ M. D. Poulik, Nature, I8o (1957) 477.

${ }^{6}$ J. SJöguist, Biochim. Biophys. Acta, 4I (rg6o) 20.

7 S. Eriksson and J. Sjöquist, Biochim. Biophys. Acta, 45 (1960) 290.

8 J. A. Gladner and H. Neurath, J. Biol. Chem., 206 (I954) 91 I.

9 K. S. AMBe AND A. L. TAPPEL, J. Chromatog., 5 (196r) 546.

10 R. J. Winzler and D. Glick, Methods of Biochemical Analysis, Vol. 2, Interscience Publishers, Inc., New York, I955, p. 290.

$11 \mathrm{O}$. W. Neuhaus and M. Letzring, Anal. Chem., 29 (1957) 1230.

12 J. Werner and L. Odin, Acta Soc. Med. Uppsala, 57 (I952) 230.

\footnotetext{
${ }^{\star}$ See p. $53^{8}$.
} 


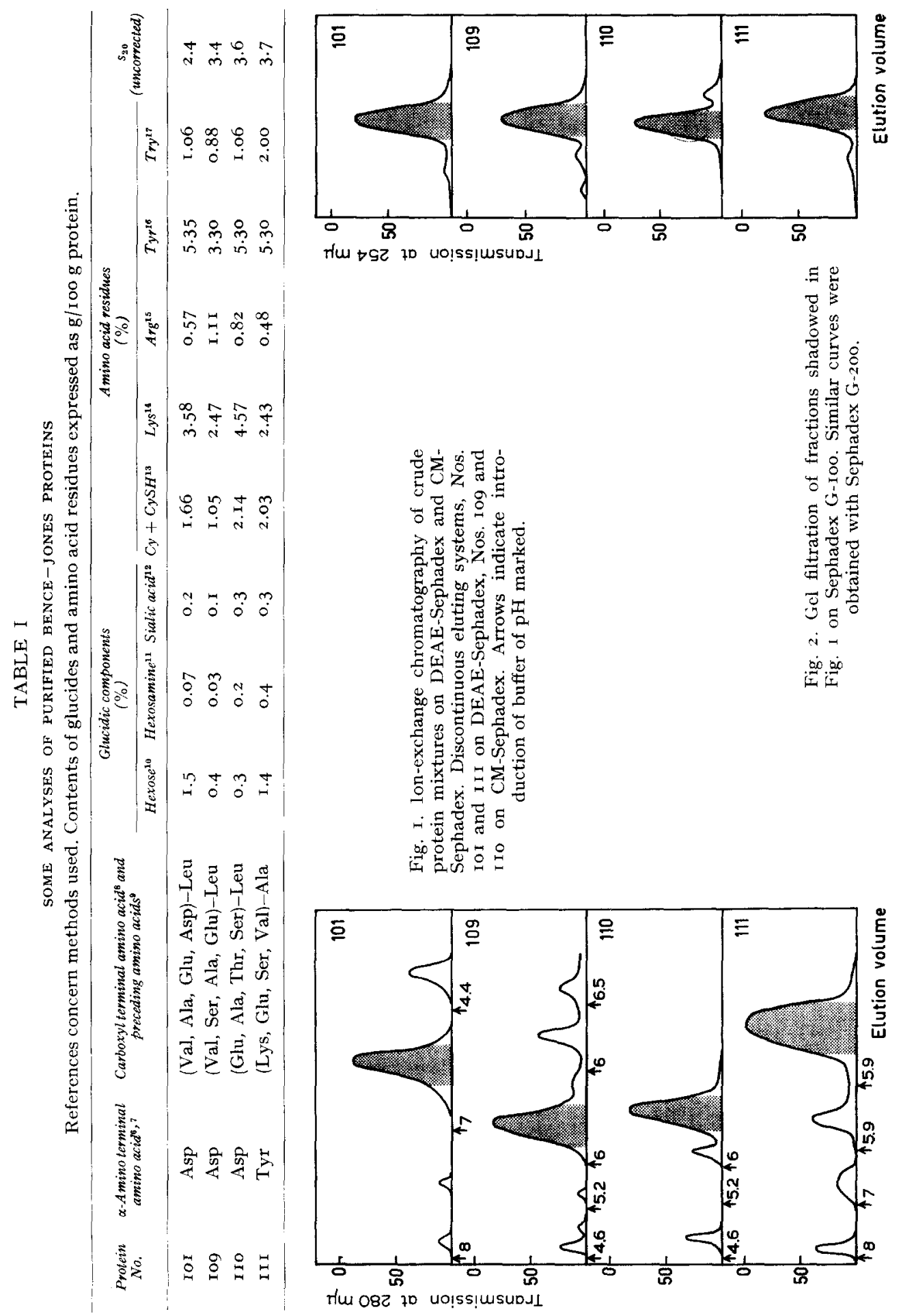


13 J. Goa, Acta Chem. Scand., I5 (I96I) 853.

14 W. H. Stein and S. Moore, J. Biol. Chem., 2 I I (I954) 893.

15 G. Ceriotti and R. Spandrio, Biochem. J, 66 (1957) 603.

16 G. Ceriotti and R. Spandrio, Biochem. J., 66 (I957) 607.

17 R. J. Spies and D. C. Chambers, A nal. Chem., 2 I (I949) 1249.

Received July Igth, I962

Biochim. Biophys. Acta, 63 (1962) 537-539

PN II 49

\section{Structural relationships among normal human $\gamma$-globulin, myeloma globulins, and Bence-Jones proteins}

In the study of structural relationships among normal and pathological globulins, Bence-Jones proteins should provide a valuable link since they exhibit many general relationships to normal human serum $\gamma$-globulin. These include common antigenic determinants, similar amino acid composition, and a common site of synthesis-the plasma cell1. From isotopic studies we had earlier postulated that Bence-Jones proteins represent abortive products of myeloma-globulin synthesis ${ }^{2}$. By comparison of the tryptic peptides we have now obtained the first chemical evidence for structural similarities among Bence-Jones proteins, the autologous abnormal globulin, and normal human $\gamma$-globulin. We propose that Bence-Jones proteins represent incomplete or aberrant polypeptide chains of normal human $\gamma$-globulin. This accords with the fact that $80 \%$ of Bence-Jones proteins have an $s_{20}=3.5 \mathrm{~S} \pm 0.25$ with a molecular weight of $45000^{1}$ and thus resemble in size the fragments obtained by oxidative ${ }^{3}$, reductive ${ }^{3,4}$ and enzymic cleavage of human $\gamma$-globulins ${ }^{5-7}$.

Peptide maps have been compared for pooled human $\gamma$-globulin, 7 purified pathological globulins, and 8 Bence-Jones proteins. The abnormal globulins represented 3 immunological types and several end-group types and included myeloma globulins and a macroglobulin. 5 of the Bence-Jones proteins were of immunological Type A and 3 of Type B (ref. 8). Like the myeloma globulins the Bence-Jones proteins differ individually in physical and chemical properties.

Fig. I contains a tracing of a composite peptide map ${ }^{\star}$ for a mixture of a 7 -S $\gamma$-type myeloma globulin and the Bence-Jones protein from the same patient ${ }^{10}$. Fig. 2 has a similar composite peptide map for the same myeloma globulin and normal human $\gamma$-globulin. The peptides identified in the separate digests are so marked that a cross-hatched area results where the 2 proteins have a spot in common. Only peptides designated $B_{1}-B_{20}$ were found in the Bence-Jones protein which was of antigenic Type B. It is evident that almost all the peptides of this Bence-Jones

* The proteins were oxidized with performic acid and digested with trypsin for $18 \mathrm{~h}$ at $37^{\circ}$. The peptides were separated by chromatography in butanol-acetic acid-water followed by electrophoresis at $\mathrm{pH} 3.7$ in pyridine-acetate buffer for $\mathrm{I} \mathrm{h}$ at $2000 \mathrm{~V}$ as described by KATz et al. ${ }^{9}$. The increase in leucine equivalents when measured by the ninhydrin method varied from Ioo$160 / 160000 \mathrm{~g}$ for normal $\gamma$-globulin and the myeloma globulins and was about $25-30 / 45000 \mathrm{~g}$ for the Bence-Jones proteins. The peptide spots were developed with ninhydrin and photographed immediately. Thus far, only a few peptides have been eluted, hydrolyzed, and analyzed with the automatic analyzer, but more than roo peptide maps have been made. 